that dignity; but unless a physician be a man of that rare talent which would perhaps qualify him for any profession or position, however exalted, and also a man of the most varied and profound learning, continually kept up to the current rate, he can never get beyond the state of miserable probation known as ' general practice.' And when that extraordinary combination of the highest faculties that constitutes a superior physician or surgeon has full scope, what is the loftiest honour to which the man can possibly attain in this country? That of a simple baronet. Why, chance has procured the creation of a greater number of baronets out of the class of ignorant tradesmen, than all the skill, all the science, all the learning, and all the humanity, of the healing art, amongst its most distinguished professors.

But this is not all the wrong that the medical profession has had inflicted on it; the denial of justice would not be complete as an offence against that profession, unaccompanied with the imposition of indignity. In future history, it will be perused with astonishment that the men to whose skill and care the lives of the community are entrusted were not deemed fit to associate with the half-educated subaltern officers of our men of war. It was not until the close of the last session of Parliament that the medical officers of the navy were suffered to mess with the lieutenants; and that right was only obtained upon the constant application of some independent members of the House of Commons, from a reluctant Admiralty Board.

Yet of the dignity as well as the importance of the medical profession there can be no question. Christ himself practised the healing art, at the same time that he decried and denounced the profession of the law. Medical men again are subject to a strict examination as to their proficiency; whereas, in the case of lawyers-that is to say, of barristersnone is required, except a mere formal one; and the examination needed for admission into the ranks of the clergy is a mere solemn farce. But the Church and the law monopolize all the professional honours accorded by the present constitution of society, and the greater part of the pecuniary emoluments. The law, for instance, has a host of judgeships, Lord Chancellor, Vice-Chancellor, commissioners, and a cloud of other appointments, home and colonial, for its followers. Contrast these rewards and honours with the slender pay of medical men in any of the services, and the maximum dignity to which they can attain. The utmost they ever arrive at is sometimes a baronetcy or knighthood, empty titles for their nnceasing toil, night and day, in private practice. Then the church has its archbishoprics, its bishoprics, its deaneries, its rectories, its crowd of profitable and honourable employments wherewith to retribute those who take up the Cross, no matter how soon or how completely they lay it down for ever, after they have been thus amply provided for. What has the medical profession in store for it - a title without a pecuniary honorarium, at least, from the country-" a name, an empty name" - vox et preterea nithil.

The people of England are very properly most sensitive on all that relates to black slavery, but it ought not to forget that of the whites at home. Half a million is expended on an imperfect African blockade; but there is the greatest hesitation manifested in making one or two medical appointments for the protection of the poor, and the satisfaction of their medical attendants. It should be remembered that the president of the Poor-law Board is a barrister, that the Home Secretary, Sir George Grey, is a barrister, and that half the inspectors are barristers, not including Lord Courtney. The medical profession are therefore justly dissatisfied. They see all appointments of profit and honour created for, and given to, barristers; they see the reform in the Church, creating new bishoprics instead of working clergy; and they see a large standing army, in which the officers, not content with their own service, are seeking and obtaining all the civil offices also. A case in point is particularly repugnant to their feelings: the lunacy commission contains only three medical men, who are expected to inspect all the lunatics of the kingdom.

It is not, therefore, astonishing that the indignation of the medical profession should be roused at the injustice that has been done to them; nor is it discreditable to them, but the contrary, that they should resolve, by every means within their power, to obtain an equal share of consideration on the part of the State with the other liberal professions. The first step has been taken in the case of the assistant-surgeons of the navy; as a beginning it has been most auspicious, and the furst step is always the greatest difficulty."

\section{LETTER TO SIR GEORGE GREY FROM THE COUNCIL OF THE COLLEGE OF SURGEONS.}

Royal College of Surgeons of England, July 22,1850 .

SIR,-I am directed by the Council of the Royal College of Surgeons of England to acknowledge your communication of the 12th ultimo.

The Council, in compliance with the desire of Secretary Sir George Grey, have carefully reconsidered the points to which he has drawn their attention.

To the first statement in your letter-viz., "The resolutions propose to exclude from the Council every fellow of the College who has directly or indirectly practised pharmacy; and further, every fellow who resides at a greater distance than five miles by highway or road, from the General Post-office at St. Martin's-le-Grand." The Council beg leave respectfully to object that the disqualifications in question do not belong to their recent resolutions, but are provisions of the charter now in force. The Council, in framing the resolutions which they have had the honour of submitting to Secretary Sir George Grey, did not indeed propose to abolish these disqualifications; but with the sincere desire of removing all legitimate causes of discontent, they are of opinion that the concessions already made in the proposed changes in the constitution of the College, are as large and liberal as are compatible with the main. tenance of any College which may merit the name of a College of Surgeons. They cannot therefore but lament that Secretary Sir George Grey "has reason to believe that the refusal to admit into the Council any fellow whatever to whom it can be objected that he practises, or has within five years practised pharmacy, would create much dissatisfaction:" but they may be permitted to observe, that they would have been more capable of furnishing a satisfactory answer to the complaints which have reached Secretary Sir George Grey, had they had the advantage of knowing upon what reasonable grounds those who practise pharmacy claim a right of eligibility to the Council; and at the same time they cannot but think that it properly devolves on the claimants to establish any right which they may assert in opposition to the express provisions of a Royal charter, or at least to show that the concession of any such claim would be productive of benefit to the profession, or to the community.

The Council cannot suppose that Secretary Sir George Grey is disposed to disregard the Charter granted by Her Majesty in 1843 to the College of Surgeons; and they beg to remind him that it was the result of the earnest study of the Council and of Her Majesty's Government of that period, to effect all the reforms calculated to render the College an efficient institution for the promotion of the art and science of surgery. Yet, in this, as well as in all the preceding charters, the principle of the ineligibility to seats in the Council of those who practise pharmacy has been uniformly adopted; and it cannot be doubted that the conversion of the College of Surgeons into an institute of general practitioners, or as they have heretofore been styled, surgeon apothecaries, would be as fatal to the character of the College as it would be contrary to the intention with which it was incorporated.

The Council can hardly think it necessary to point out that the professional class evidently contemplated in the several charters as comprising those peculiarly qualified for the office of member of Council, consists of surgeons of hospitals, teachers of anatomy and surgery; those who have distinguished themselves by original observations and discoveries in surgery, and the collateral branches of science; eminent practitioners, including those who hold honorary appoint ments, and in general all those whose aid is anxiously sought in dangerous accidents, in delicate operations, and in serious surgical complaints; but considering that Secretary Sir George Grey apprehends that the exclusion of those who practise pharmacy "would create much dissatisfaction," the Council feel themselves bound to state, as their deliberate conviction, that those who have established the proof of their especial and successful devotion to the study and practise of surgery are those best fitted to act collectively for the advancement of surgical science, and therefore best qualified to be entrusted in a collegiate capacity with the functions of superintending the education, and of conducting the public business, of the surgical profession. On the other hand, the Council believe that the claims of surgeon-apothecaries, or general practitioners, to seats in the Council, may be best appreciated by the fact that they are almost universally engaged in medical practice, and have few opportunities to practise surgery, and fewer inducements to cultivate it as a science. The exceptions to the rule are the surgeons in the provinces, who are 
attached to hospitals; who are connected with mining or mantufacturing establishments, the operations of which are productive of manifold injuries, requiring surgical aid; or who have obtained a deserved reputation as the consulting and operating surgeons of the districts in which they reside. To these, and they are not a few, the Council, bearing a cordial testimony to their high professional character, would most willingly, notwithstanding they "practise, and are under the necessity of practising pharmacy," extend the right of eligibility to the Council; but they confess their inability to draw any line which shall include those practising pharmacy, whose professional qualifications may entitle them to seats in the Council, and which shall exclude those practising the same, who have no such pretensions on the score of superior skill and knowledge in surgery. The Council have therefore arrived at the conclusion, in accordance with the provisions of the Charter of their College, that it is indispensable to the maintenance of sound chirurgical knowledge, and no less to the interests of the profession and of the public, that the government of the College should never be entrusted to those who, practising pharmacy, have been immemorially designated as apothecaries.

In reconsidering the provision of the present charter, which excludes from the council "every fellow of the college who resides at a greater distance than five miles by highway or road from the General Post-office at St. Martin's-le-Grand," the council see no reason to recommend any alteration therein. They are of opinion that fellows "actually practising their profession" could not perform the duties which devolve upon them as members of council should their residence be at a greater distance from the metropolis; and they beg to remind Secretary Sir George Grey that a seat in the council is not a mere honorary distinction, or that it requires only regular attendance at stated meetings of the Council, but that a large amount of the business of the College is necessarily transacted in committees, and that the meetings both of the Council and of committees are often the result of unexpected calls. The meetings of Council during the past year have been no less than twenty-two; and the meetings of committees, during the same period, have amounted to thirty-four. From this statement it will be evident that the exclusion, which it is presumed will cause dissatisfaction, arises simply from the fact that fellows of the College residing at a distance from London cannot perform the duties which devolve upon them as members of Council; and it is quite clear that there is no assignable reason for excusing them from the duties which they would be bound to fulfil.

The Council remark that Secretary Sir George Grey " is anxious to receive some further explanation of the views held by the Council upon the subject of the alliance and union of the two London Colleges with the Universities," and they trust that the solicitude stated to be expressed by the deputations, in their interviews with Secretary Sir George Grey, is favourable to a design which the Council believe to be fraught with advantages to the profession. They beg to be permitted to hold themselves excused from pledging themselves to any specific plan, since its definitive arrangement obviously requires the consent and agreement of other parties; but they would most gladly avail themselves of the sanction of Her Majesty's Government to open, conjointly with the College of Physicians, a negotiation with the Universities, and especially with the University of London, as most interested in the proposed measure.

The Council, further, are desired to express their views "6rith regard to that class of medical practitioners, not members of the College, who have been termed general practitioners and whose incorporation as a body has been strongly pressed."

The Council feel some difficulty in furnishing a suitable and satisfactory statement in reply to this request. The meaning which they attach, and which they presume would be legally attached, to the term " general practitioner," is the designation of one who has obtained the diploma of the College of Surgeons, either as member or fellow, and the licence of the Society of Apothecaries, and who, in conformity therewith, practises as surgeon, apothecary, and accoucheur ; such general practitioners constitute the larger part of the class, who, possessing the qualification, medical and surgical, required by the poor-law commissioners, are appointed as medical officers of poor-law unions. Such are the general practitioners whom the National Institute professes to repre. sent, and of whom they urge the incorporation as a College of General Practitioners.

Other than these, the Council know of no practitioners who can be designated, with any degree of propriety, "general practitioners."
There are, indeed, some, and the Council believe they are not numerous, who, practising as apothecaries and accoucheurs, are merely licentiates of the Society of Apothecaries, and are not members of the College of Surgeons; but who can scarcely, or only by a lax use of words, be considered to have any title to the character of general practitioners. The Council are ignorant of any claim, on the part of such licentiates, to be separately incorporated, or that their incorporation forms a part of any "scheme that has been strongly pressed."

The plan contemplated by the representatives of the general practitioners in connexion with the institution of a College of General Practitioners, and assented to by the representatives of the College of Surgeons, at the conferences held at the College of Physicians, had for its express object that, after the passing of the proposed Bill, all general practitioners should be required to have been admitted both to the College of Surgeons and to the College of General Practitioners, and to be registered accordingly. The council of the college believe that the necessity of a double qualification, medical and surgical, in the case of general practitioners, has been uniformly admitted, whatever differences of opinion may exist with regard to medical corporations and their powers to license. In accordance with this view, they have recommended, in their late communication with Secretary Sir George Grey, that the general practitioner should obtain his licence to practise medicine, surgery, and mid wifery, by passing suitable examinations at the College of Physicians, and College of Surgeons; and they venture to add, that in the organization of the whole profession it would be inexpedient, and inconsistent with the prevailing social arrangements, to recognise, or to incorporate as general practitioners, those medical practitioners who have no surgical qualification.

Finally, the council, after a deliberate review of the propositions which they had the honour of submitting to Secretary Sir George Grey, in their letter dated April 23rd, can discover no reason for changing the opinions which they then expressed, or for making any further alterations in the constitution of the college than those proposed in the above communication; and they trust that their proceedings will be, and at no distant period, accepted by those of their members who call themselves general practitioners, as the result of a sincere desire for maintaining the efficiency and dignity of the profession of surgery.

(Signed) I have, \&c. EDMund Belfotr, Sec.

\section{REPORT OF THE NATIONAL INSTITUTE OF MEDICINE, SURGERY, AND MIDWIFERY. \\ To the Editor of The LANCET.}

Office, 4, Hanover-square, Sept. 14, 1850.

Sir,-I am directed to forward to you the accompanying copy of the Report of the general committee, submitted to, and approved by, the council of the National Institute, at their quarterly meeting, held at the Hanover-square Rooms, on Wednesday last, the 11th inst., and to request of you the favour to publish it in the next number of THE KaNcET.

I am, Sir, your most obedient servant, Herbert Wiluams, Sec. pro tem.

\section{REPORT.}

The committee, in accordance with the resolution of the council agreed to at the last meeting, took immediate steps to place the Bill for the incorporation of the general practitioners in the hands of James Wyld, Esq., M.P., in order that it might be presented to Parliament as speedily as possible; and they are enabled to report that the Bill was laid on the table of the House on the 23rd of July last, with an understanding between that gentleman and the Government that it should not be proceeded with during the then session of Parliament: the Bill has since been prirted, by order of the House of Commons.

With the view of securing future co-operation in support of the proposed measure during the ensuing session of Parliament, and also of increasing the pecuniary resources of the Institute, the committee have deemed it expedient to forward the following note to those gentlemen who, although not members of the Institute, are in favour of the incorporation of general practitioners:-

$$
\begin{aligned}
& \text { “ The National Institute of Medicine, Surgery, and Midwifery, } \\
& \text { 4, Hanover-square, August 20, } 1850 .
\end{aligned}
$$

SIR,-I am directed by the Council of the National Institute to inform you, that the Bill framed for the Incorporation of the General Practitioners has been presented to the House of Commons by James Wyld, Esq., and Colonel Thompson, and 